\title{
The Relationship between Listing Requirements and Market Quality: An Examination Using NASDAQ's Tiered Market Structure
}

\author{
Kevin D. Broom ${ }^{1} \&$ Jason S. Turner ${ }^{1}$ \\ ${ }^{1}$ Department of Health Management \& Policy, Saint Louis University, St. Louis, USA \\ Correspondence: Kevin D. Broom, Department of Health Management \& Policy, Saint Louis University, St. Louis, \\ Missouri, USA.
}

Received: September 1, 2016

Accepted: September 20, 2016

Online Published: October 20, 2016

doi:10.5430/ijfr.v7n5p203

URL: http://dx.doi.org/10.5430/ijfr.v7n5p203

\begin{abstract}
This study examines the relationship between listing requirements and market quality. Related studies analyzed market quality by focusing on disclosure requirements, while neglecting potential effects from listing requirements. Most of these studies failed to control for different market structures, thereby creating joint hypothesis problems. Using the unique structure of NASDAQ, We examine market quality while controlling for disclosure requirements and market structure. We find a significant relationship exists between listing requirements and four measures of market quality. The results indicate that listing requirements represent the types of information revealed, whereas disclosure requirements represent the mechanism through which markets reveal information.
\end{abstract}

Keywords: disclosure, listing, market quality, liquidity, NASDAQ

\section{Introduction}

This study analyzes the relationship between listing standards and market quality. Using the Chemmanur and Fulghieri (2006, denoted CF hereafter) framework as a theoretical motivation, we examine whether a relationship exists between the listing requirements for NASDAQ-listed stocks and four measures of market quality. Under the CF framework, exchanges use both disclosure and listing standards to attract listings and to produce information useful in the pricing of assets. This process of creating information could lead to a more transparent trading environment. From a firm's perspective, a more transparent marketplace would lead to less volatility and lower transaction costs, thereby enhancing shareholder wealth through reducing cost of capital.

Previous related studies focused on the effects of different disclosure requirements on market quality. These studies analyzed market quality characteristics for stocks listed on different exchanges, and sometimes in different countries. Thus, these studies suffered from a joint hypothesis problem. Any documented effects attributed to disclosure requirements were left comingled with microstructure effects due to the sample stocks being drawn from various market structures, which is well documented in the literature. Additionally, the effects due to disclosure requirements were comingled with potential effects of different listing requirements, because the sample stocks were drawn from numerous exchanges with different listing requirements.

In this study we use NASDAQ's unique tiered structure to control for both disclosure requirements and market structure to resolve the joint hypothesis problem, while focusing on any relationship between listing requirements and market quality. My cross-sectional analysis indicates that real market quality differences exist across the tiers, and the differences are related to common listing requirements. However, a short-term analysis of changes in market quality (as companies change tiers) fails to detect any material changes in the 20 trading days immediately after a firm switches tiers. The combination of the cross-sectional and temporal analysis confirms listing standards are related to market quality, but that market quality does not immediately change when a company moves onto a tier with different listing requirements.

Two possible explanations arise. First, the disclosure process could be inefficient, as market quality evolves slowly through the disclosure process, rather than instantly upon the application of new listing standards. Second, the disclosure process is highly efficient, where market quality already reflects information contained in the new listing standards. Given that previous research already documents a relationship between disclosure requirements and market quality, future studies should focus on the efficiency of the disclosure process as it relates to market quality. 
The rest of the study is organized as follows. Section 2 reviews related literature and describes the unique NASDAQ structure. Section 3 describes the data and methodology. Section 4 presents the empirical findings, and Section 5 concludes.

\section{Literature Review and NASDAQ Structure}

\subsection{Literature Review}

$\mathrm{CF}(2006)$ propose a theoretical framework where exchanges use disclosure and listing standards as a means to aid investors in the production of information that is useful in accurately pricing assets traded in their marketplace. Listing standards enable exchanges to screen potential listings for their exchange, and to apply stringency when investigating and enforcing disclosure requirements of those listed firms.

In the case of NASDAQ, the disclosure and listing standards provide the public with information on each firm's size, earning power, and governance, as well as the overall level of public interest in the firm's stock. As a result, NASDAQ's listing and disclosure requirements help a) monitor listing firms and b) enhance the precision of information made available to outsiders when evaluating those firms. Thus, listing and disclosure process should result in more a transparent marketplace.

Higher listing and disclosure standards do come at a cost to the exchange though. If the exchange sets high listing standards, the exchange reduces the number of firms that will qualify for listing. This smaller pool of potential firms reduces the expected cash flows (from the listing fees) that serve as a major source of revenue for the exchange. Additionally, the smaller number of qualifying firms reduces the revenue generated through individual transactions in the marketplace as assets exchange hands (CF, 2006; Easley and O'Hara, 2007). Likewise, higher disclosure standards may cause the exchange to incur "greater verification and regulatory costs to verify and regulate disclosures made by these firms (CF, 2006)."

While CF's framework addresses both disclosure and listing requirements, prior research focused solely on the relationship between disclosure and market quality. Welker (1995), Healy, Hutton, \& Palepu (1999), and Leuz and Verrechia (2000) all find positive relationships between disclosure and liquidity, but their studies focus solely on transaction costs. Heflin, Shaw, \& Wildo (2005) also find a positive relationship by focusing on both transaction costs and depth.

While Frost and Botosan (1997) and Frost, Gordon, \& Hayes (2006) find a positive relationship between disclosure requirements and liquidity, their studies suffer from a joint hypothesis problem. Frost and Botosan (1997) find that less regulation and fewer disclosure requirements result in lower liquidity. In their analysis of non-US firms listed on NYSE, NASDAQ, and the OTCBB from 1994-1996, they fail to isolate the liquidity effects resulting from disclosure requirements, listing requirements, and three different market structures. Likewise, Frost et al. (2006) find that stronger disclosure systems are related to higher levels of liquidity. However, they analysis results in the same joint hypothesis problem due to analyzing liquidity across 50 different exchanges.

Chavez and Silva (2006) study the liquidity impact when the Sao Paulo Stock Exchange created a special listing segment requiring firms to have financial statements prepared in accordance with International Accounting Standards or GAAP, thereby resulting in higher disclosure standards on the new segment. They found that liquidity increased (i.e. transaction costs decreased) when firms voluntarily choose to move to the new segment. However, this study consisted of only 62 firms, and did not test for any liquidity changes for the firms choosing not to list in the special segments.

Draus (2009) proposes a separate framework where an exchange can improve the liquidity of assets which trade on its exchange by tightening its listing requirements. The tightening of listing requirements reduces information asymmetry about a firm, increases the firm's liquidity, and leads to higher levels of investor participation.

\subsection{NASDAQ Structure}

NASDAQ's unique, tiered structure allows for a natural experiment where market quality differences resulting from disclosure requirements and market structures can be controlled. Using NASDAQ-listed firms ensures that all sample stocks trade on similar market structures (e.g. such as dealer vs. auction, floor-based vs. electronic, or quote vs. order-driven). The tiers have the same trading rules, such as short-sale price tests, different treatment of limit orders, or opening/closing procedures. All three NASDAQ tiers also have the same potential competitors for order flow, such as alternative trading systems and regional exchanges, through their unlisted trading privileges.

The distribution of stocks across the NASDAQ tiers is shown in Table 1. This current structure results from a 2006 restructuring in which NASDAQ created a third tier with the "highest listing standards in the world" (NASDAQ 
Press Release, 2006). The newest tier resulted from NASDAQ subdividing their formerly named NASDAQ National Market into the new Global and Global Select Markets. Meanwhile, the NASDAQ Smallcap Market was simply renamed the NASDAQ Capital Market.

Table 1. Changes in NASDAQ Tier Listings, 2006-2008

\begin{tabular}{|l|c|c|c|}
\hline \multicolumn{1}{|c|}{ Tier } & Jul-06 & Dec-08 & Change \\
\hline Global Select Market & 1,140 & 1,222 & 82 \\
\hline Global Market & 1,353 & 1,116 & $(237)$ \\
\hline Capital Market & 529 & 497 & $(32)$ \\
\hline Total & 3,022 & 2,835 & $(187)$ \\
\hline
\end{tabular}

NASDAQ specifies the characteristics that distinguish the three tiers of stocks in their NASDAQ Listing Requirements. The listing requirements identify the financial and liquidity characteristics required for trading on a specific tier. Appendices A and B provide the initial and continued listing standards for each tier at the time of the restructuring. Each trading day, when companies fail to meet a listing requirement, NASDAQ posts a list of non-compliant companies on its website. The listing indicates the issuer name, the listing deficiency, the market on which the asset trades and the date NASDAQ initially notified the firm of the delinquency.

NASDAQ does not have its own unique disclosure requirements. While disclosure requirements are outlined in the NASDAQ Listing Rules, NASDAQ enforces the reporting requirements of the Exchange Act and the disclosure requirements of Regulation FD for NASDAQ-listed firms. NASDAQ has a team of analysts responsible for policing the reporting and disclosure of firms listed on their exchange. Each of their analysts is assigned up to 200 firms to monitor, and the analysts are responsible for verifying that firms meet, and continue to meet, the initial and continued listing requirements for the tier to which they are assigned. Additionally, analysts monitor when the listed firms are required to disclose routine information such as quarterly and annual reports, earnings and dividend announcements, etc.

Whenever the company fails to meet a mandated disclosure timeline, the analysts are responsible for notifying the listed firm to inquire into the nature of the delay. NASDAQ may require the firm to conduct a press release notifying investors of the delay, as well as disclosing any information about the delay that may be material in accurately pricing their stock trading on NASDAQ. If the firm fails to comply, NASDAQ could take measures ranging from initiating/extending trading halts to delisting the firm.

\section{Data and Methodology}

\subsection{Data}

This study uses two data sets. The cross-sectional data consists of all stocks listed on NASDAQ over the 90 calendar days immediately after the July 3, 2006 restructuring. The three data sources are the Center for Research in Security Prices (CRSP) database, Standard \& Poor's Compustat North America database, and the Rule 605 data set.

The CRSP database serves as the primary data source for identifying all NASDAQ-listed stocks, as well as to which tier they are assigned. Standard \& Poor's Compustat North America database serves as a second data source, providing the firm-specific data identified in the NASDAQ listing requirements. SEC-mandated Rule 605 data serves as the third data source for the cross-sectional dataset. The SEC requires market centers trading NMS securities to report order execution quality data, on a stock-by-stock basis, under the SEC's Rule 605 of NMS (formerly known as Exchange Act Rule 11Ac1-5). This data is made publicly available through the Transaction Auditing Group, Inc. Since Compustat provides quarterly data, and Rule 605 data provides monthly data, all market quality measures using the Rule 605 data will also require conversion to quarterly measurements using both equally-weighted and value-weighted calculations. The initial data set consists of 2,667 firms.

The second data set is used to identify any immediate changes in market quality resulting from stocks moving between tiers. This data set consists of all stocks listed on NASDAQ for a 30-month period (from July 2006 until Dec 2008) after the restructuring. Three data sources are used to create the data set for this analysis: CRSP, the SEC's EDGAR database, and the NYSE's Trade and Quote (TAQ) database.

CRSP identifies when companies move between tiers. In some cases of missing data, the SEC's EDGAR database identifies the implementation dates of firms moving between tiers. TAQ contains intraday transactions data (trades 
and quotes) used to calculate daily observations of the Rule 605 market quality characteristics. The second dataset consists of 158 stocks that switched tiers during this timeframe, with 84 rising to a higher tier, and 74 dropping to a lower tier.

\subsection{Methodology}

Numerous measures of market quality are used in the microstructure literature, including such measures as spreads, depth, volatility, price impact, price efficiency, market efficiency, execution speed, order flow fragmentation, speed of price adjustment, locked/crossed markets, and market quality index (Theobald \& Yallup, 2004; Bennett \& Wi, 2006; Zhao \& Chung, 2007; Eom, Ok, \& Park, 2007; Hendershott \& Jones, 2008; Alexander \& Peterson, 2008; Shkilko, Van Ness, \& Van Ness, 2008). Since the Rule 605 data contains market quality characteristics on spreads, rate of price improvement, amount of price improvement, and fragmentation of order flow, this study focuses on these measures of market quality.

For the cross-section analysis, the following measures of market quality are analyzed:

1. Dependent Variables (Market Quality Characteristics):

a. Percentage Average Effective Spread (Eff Spr): Measures the cost traders bear when buying or selling an asset. Defined in Rule 605 (paragraph (a)(2)) as the share-weighted average of effective spreads for order executions, calculated for sell (buy) orders as double the amount of difference between the best bid and offer midpoint (execution price) at the time of order receipt and the execution price (midpoint). Quarterly measures of the percentage average effective spread will be calculated for each stock using both equally and value-weighted approaches, and separately for market, marketable limit, inside-the-quote limit, at-the-quote limit, and near-the-quote limit orders.

b. Price Improvement Rate (PI Rate): Measures the percentage of shares executed with price improvement. Quarterly measures of the price improvement rate will be calculated for each stock using both equally and value-weighted approaches, and separately for market, marketable limit, inside-the-quote limit, at-the-quote limit, and near-the-quote limit orders.

c. Price Improvement Amount (PI Amt): Measures the average amount per share, as a percent of share price, that prices were improved for orders with price improvement. Quarterly measures of the price improvement amount will be calculated for each stock using both equally and value-weighted approaches, and separately for market, marketable limit, inside-the-quote limit, at-the-quote limit, and near-the-quote limit orders.

d. Order Flow Fragmentation (HHI): Measures the concentration of order flow across all major market centers. Quarterly measures of order flow fragmentation will be calculated for each stock using the Herfindahl-Hirschman Index (HHI). The HHI will be calculated using both equally and value-weighted approaches, and separately for market, marketable limit, inside-the-quote limit, at-the-quote limit, and near-the-quote limit orders. HHI is defined as:

$$
H H I=\sum_{i=1}^{n} S_{i}^{2}
$$

where $S_{i}$ is the market share of each major market.

Appendices A and B show the initial and continued listing standards for each tier in effect when NASDAQ created the NGM and GSM. An examination of the listing standards shows five common characteristics across tiers, where NASDAQ applies increasing thresholds of those criteria for inclusion on a higher tier. These characteristics are stock price, number of registered market makers, stockholders' equity, number of publicly held shares, and the market value of publicly held shares. Since these criteria reveal a consistent set of information across tiers, they will form a vector of variables of interest in order to test the relationship between listing requirements and market quality.

2. Variables of Interest -

a. Bid Price (PRC): The bid price is the price per share at which market makers will purchase the stock (sourse is CRSP, "PRC"). CRSP provides daily measures, so the end of period bid price will be used.

b. Market Makers (MMCNT): The number of market makers is the number of registered market makers for the issue (sourse is CRSP, "MMCNT"). CRSP provides daily measures, so the end of period market maker count will be used. 
c. Stockholders' Equity (SE): The stockholders' equity is the total common and preferred shareholders' interest in the company, and includes: capital surplus, common/ordinary stock, redeemable and nonredeemable preferred stock, retained earnings, and treasury stock (source is Compustat, "Stockholders' Equity - Total"). Compustat provides quarterly measures of the Stockholders' Equity for each issue, measured in millions, that corresponds to the period end date.

d. Shares Outstanding (SHROUT): Represents the number of publicly held shares (source is CRSP, "Shares Outstanding - Adjusted"). CRSP provides daily measures of the Number of Shares Outstanding, measured in thousands, for each issue, that corresponds to the period end date.

e. Market Value of Public Shares (MktVal): Represents the combined market value of all publicly held shares, calculated by multiplying quarterly measures of [Bid Price * Publicly Held Shares].

Aside from testing for relationships between the variables of interest and the market quality measures, we also test for any further market quality differences across the tiers that are unrelated to the common listing requirements. Any further differences in market quality could be related to the unique listing requirements of each tier. Since NASDAQ has three tiers, the methodology treats the middle tier (NGM) as the base case, and uses dichotomous variables to capture any further market quality differences for the upper (GSM) and lower (NCM) tiers that are unrelated to the vector of variables of interest.

3. Dummy Variables -

a. Global Select Market (GSM): Dummy variable equal to 1 if the stock is listed on the Global Select Market, and 0 otherwise.

b. NASDAQ Capital Market (NCM): Dummy variable equal to 1 if the stock is listed on the NASDAQ Capital Market, and 0 otherwise.

For further examination, we employ an event study methodology to test for short-term changes in market quality when a stock moves from one tier to another (firms identified as changing tiers from July 2006 - Dec 2008). A total of 158 firms switch tiers during this timeframe. This event study analysis helps clarify whether market quality immediately changes when a firm changes tiers into a new listing environment. In essence, the cross-section looks at all firms listed on each tier at a point in time, whereas the event study focuses on firms at the margins (those at the top of a lower tier, or at the bottom of a higher tier), as they migrate from one tier onto another.

For this analysis, we will use TAQ data to construct daily measures of the market quality characteristics, and then calculate equal and value-weighted averages for all firms on a specific tier for comparison. The daily measures will be calculated as follows:

Percent Effective Spread (EffSpread) for security $i$ :

$$
\text { EffSpread }_{i}=\frac{\sum_{n=1}^{N}\left(2 * I_{\text {trade }}\left(\text { Price }_{i, t}-M_{i, t}\right) / \text { Pr ice }_{i, t}\right)}{N}
$$

where $\mathrm{I}_{\text {trade }}$ is the trade direction indicator ( 1 for buys and -1 for sells) and $\mathrm{M}_{\mathrm{i}, \mathrm{t}}$ is the quote midpoint at the time of the trade. The daily observations for each stock will be calculated using both equally and value-weighted measures.

Price Improvement Amount (PI Amt) for security $i$ is defined as the average price improvement, measured as a percent of share price, for shares trading within the posted national best bid and ask prices at the time of execution.

$$
\text { PIAmt }_{i}=\frac{\left.\sum_{t=1}^{T}\left[\text { trade }_{\text {Price }} \text { ( }- \text { Quote }_{i, t}\right) / \text { Price }_{i, t}\right]}{N}
$$

Price Improvement Rate (PI Rate) for security $i$ is defined as the percentage of shares trading within the posted national best bid and ask prices at the time of execution. Daily observations will be calculated for each stock:

$$
\text { PIRate }_{i}=\frac{\# \text { Shares }_{i, w / \text { Pricelmprovement }}}{\# \text { Shares }_{i, \text { Total }}}
$$


where $\mathrm{I}_{\text {trade }}$ is the trade direction indicator (1 for sells and -1 for buys), Quote $\mathrm{i}_{\mathrm{i}, \mathrm{t}}$ is the Bid (Ask) price for sell (buy) orders, and $\mathrm{n}$ is the total number of trades during the day.

Herfindahl-Hirshman Index for security $i$ is defined as the measure of order flow concentration across exchanges for each stock:

$$
H H I_{i}=\sum_{i=1}^{n}\left(\frac{S_{i}}{S_{\text {Total }}}\right)^{2}
$$

where $\mathrm{S}$ is the share volume that occurs on Market $m$ during the trading day.

We examine changes in market quality over the 41 trading days surrounding the tier change ( 20 days before, the event day, and 20 days after). We use the implementation date as shown on CRSP, or in the SEC filings listed on the EDGAR database when CRSP data was missing. We omit trades and quotes if the data indicates that they are out of time sequence or involve either an error or a correction. We also omit quotes if the ask and/or bid prices are equal to or less than zero, and we omit any trades where the price and/or volume is equal to or less than zero.

\section{Evidence}

Table 2, Panel A provides a descriptive analysis on the size of NASDAQ's three tiers, the distribution of listing characteristics on each, and the market quality characteristics for each tier. First, note that the GSM and NGM both have over twice as many firms listed as the NCM. Both tiers have over 1,000 firms throughout the 90-day sample period. In contrast, the NCM has fewer than 500 firms listed. The firm characteristics indicate, as expected by the nature of NASDAQ's listing characteristics, when moving from the lowest tier (NCM) to the highest (GSM), firms become larger, have a higher public float, have greater amounts of contributed capital, more dealer interest, and higher stock prices. When firm size is measured by the market value of publicly held shares, the average GSM firm is over ten times as large as a NGM firm, and almost 30 times as large as the average NCM stock. Stockholders' Equity shows a similar relationship.

Table 2. NASDAQ listing and market quality statistics

\begin{tabular}{|c|c|c|c|c|c|c|c|c|c|}
\hline $\begin{array}{l}\text { Panel A: Descriptive Statistics for Firm } \\
\text { Characteristics }\end{array}$ & \multicolumn{3}{|c|}{$\operatorname{GSM}(\mathrm{n}=1,039)$} & \multicolumn{3}{|c|}{$\operatorname{NGM}(\mathrm{n}=1,192)$} & \multicolumn{3}{|c|}{$\operatorname{NCM}(n=436)$} \\
\hline \begin{tabular}{|c|} 
Variable \\
\end{tabular} & Min & Mean & Max & Min & Mean & Max & Min & Mean & Max \\
\hline Bid Price & $\$ 2.14$ & $\$ 27.90$ & $\$ 410.61$ & $\$ 0.32$ & $\$ 11.91$ & $\$ 114.79$ & $\$ 0.44$ & $\$ 9.25$ & $\$ 111.43$ \\
\hline \# Mkt Makers & 14.50 & 39.92 & 97.50 & 11.00 & 28.21 & 73.50 & 11.00 & 20.31 & 53.50 \\
\hline Stockholder's Equity (in \$Ms) & $(\$ 1,065.15)$ & $\$ 817.52$ & $\$ 40,314.50$ & $(\$ 5,790.50)$ & $\$ 86.11$ & $\$ 1,497.08$ & $(\$ 244.49)$ & $\$ 29.92$ & $\$ 825.60$ \\
\hline \# Publicly Available Shares (in Ms) & 3.15 & 107.08 & $9,941.00$ & 1.12 & 26.20 & 486.72 & 1.20 & 15.83 & 241.19 \\
\hline Market Value of Public Shares (in \$Ms) & $\$ 85.69$ & $\$ 2,679.27$ & $\$ 251,755.83$ & $\$ 3.37$ & $\$ 229.18$ & $\$ 7,992.03$ & $\$ 1.87$ & $\$ 95.69$ & $\$ 6,279.41$ \\
\hline \multicolumn{10}{|c|}{$\begin{array}{l}\text { Panel B: Regressions for differences between tiers. } \\
\text { The NASDAQ Global Market is the base case. NCM is a dummy variable equal to } 1 \text { if the stock is listed on the NASDAQ Capital Market, and } 0 \text { otherwise. GSM is a dummy variable } \\
\text { equal to } 1 \text { if the stock is listed on the Global Select Market, and } 0 \text { otherwise. }\end{array}$} \\
\hline \multirow{2}{*}{ 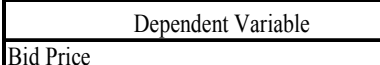 } & $\alpha$ & $\mathrm{NCM}$ & GSM & $\mathrm{F}$ & adj-r ${ }^{2}$ & & & & \\
\hline & $\$ 11.94$ & $-\$ 2.94$ & $\$ 15.83$ & 422.94 & $22.01 \%$ & & & & \\
\hline Bid Price & $0.0006^{* * *}$ & $<.0001^{* * *}$ & $<.0001^{* * *}$ & $<.0001^{* * *}$ & & & & & \\
\hline \multirow[t]{2}{*}{ \# Mkt Makers } & 28.28 & -8.23 & 11.79 & 518.25 & $25.70 \%$ & & & & \\
\hline & $<.0001^{* * *}$ & $<.0001^{* * *}$ & $<.0001 * * *$ & $<.0001 * * *$ & & & & & \\
\hline \multirow[t]{2}{*}{ Stockholder's Equity (in \$Ms) } & $\$ 86.08$ & $-\$ 56.26$ & $\$ 731.43$ & 65.22 & $4.59 \%$ & & & & \\
\hline & $0.0715^{*}$ & 0.5412 & $<.0001^{* * *}$ & $<.0001 * * *$ & & & & & \\
\hline \multirow[t]{2}{*}{ \# Publicly Available Shares (in Ms) } & $\$ 26.43$ & $-\$ 11.27$ & $\$ 77.90$ & 29.35 & $1.86 \%$ & & & & \\
\hline & $0.0006^{* * *}$ & 0.4406 & $<.0001 * * *$ & $<.0001^{* * *}$ & & & & & \\
\hline \multirow[t]{2}{*}{ Market Value of Public Shares (in \$Ms) } & $\$ 231.92$ & $-\$ 144.25$ & $\$ 2,387.26$ & 45.33 & $2.88 \%$ & & & & \\
\hline & 0.2106 & 0.6807 & $<.0001^{* * *}$ & $<.0001 * * *$ & & & & & \\
\hline \multicolumn{10}{|c|}{$* * *, * *, *$ denote statistical significance at the $.01, .05$, and .1 level of significance. } \\
\hline $\begin{array}{l}\text { Panel C: Descriptive Statistics for Market } \\
\text { Quality Characteristics }\end{array}$ & \multicolumn{3}{|c|}{$\operatorname{GSM}(n=1,039)$} & \multicolumn{3}{|c|}{$\operatorname{NGM}(n=1,192)$} & \multicolumn{3}{|c|}{$\operatorname{NCM}(n=436)$} \\
\hline \begin{tabular}{|c|} 
Variable \\
\end{tabular} & Min & Mean & Max & Min & Mean & Max & Min & Mean & Max \\
\hline$\%$ Effective Spread & $0.009 \%$ & $0.106 \%$ & $1.281 \%$ & $0.023 \%$ & $0.469 \%$ & $3.068 \%$ & $0.016 \%$ & $1.140 \%$ & $9.050 \%$ \\
\hline Price Improvement Amount & $0.010 \%$ & $0.080 \%$ & $0.679 \%$ & $0.026 \%$ & $0.250 \%$ & $2.313 \%$ & $0.013 \%$ & $0.527 \%$ & $3.706 \%$ \\
\hline Price Improvement Rate & $0.852 \%$ & $5.866 \%$ & $16.594 \%$ & $0.456 \%$ & $5.440 \%$ & $23.805 \%$ & $0.902 \%$ & $6.411 \%$ & $24.049 \%$ \\
\hline Herfindahl-Hirschman Index (HHI) & 0.5002 & 0.5831 & 0.8955 & 0.5000 & 0.6675 & 1.0000 & 0.5042 & 0.7739 & 0.9903 \\
\hline
\end{tabular}


The disparity is much smaller when considering the number of registered market makers for each stock. GSM stocks show, on average, only twice as many registered market makers as stocks on the lowest tier (NCM). While the number of registered market makers indicates the quantity of market makers capable of participating in order flow for a particular stock, it doesn't necessarily represent the level of active participation in each stock.

Panel B shows the results of tests for differences in listing characteristics between the tiers. The OLS regressions use the Global Market as the base case, with dummy variables distinguishing the Capital and Global Select Markets. NCM stocks are significantly lower priced and have fewer market makers than NGM. GSM stocks have significantly higher priced stocks, more market makers, greater contributed capital (stockholders' equity), larger public floats, and larger market values than NGM stocks. All five OLS regressions are significant, but they explain very little of the variation in firm characteristics among the tiers.

Panel $\mathrm{C}$ provides a descriptive analysis of the market quality characteristics across tiers. The market quality characteristics obtained using the Rule 605 data indicate that, when moving from the lowest tier (NCM) to the highest (GSM), effective spreads fall, the price improvement percent decreases, the rate of price improvement decreases, and trading becomes more fragmented across major market centers.

The initial analysis indicates that the tiers exhibit a market quality tradeoff as you move from the lowest to the highest tier. Effective spreads fall, indicating enhanced market quality. Yet, price improvement declines and trading becomes more fragmented, indicating decreased market quality. These results are consistent with the notion that as stocks become more heavily traded, increased competition for order flow narrows spreads and reduces opportunities for price improvement. Correlation analysis, not reported, shows no strong correlations that could pose problems with multicollinearity.

Tables 3 through 6 show the results of OLS regressions for the market quality variables. Model 1 directly tests for differences in the market quality characteristics across tiers, without considering the vector of common listing variables. The model specified is:

$$
M Q=\beta_{0}+\gamma_{1} * N C M+\gamma_{2} * G S M+\varepsilon
$$

All dummy variables are statistically significant, and all models have statistically significant F-statistics (at the $\alpha=.01$ level of significance).

Model 2 in Tables 3 through 6 shows the relationship between the vector of control variables and the four market quality characteristics. The model specified is:

$$
M Q=\beta_{0}+\beta_{1} * P R C+\beta_{2} * M M C N T+\beta_{3} * S E+\beta_{4} * S H R O U T+\beta_{5} * M k t V a l+\varepsilon
$$

All four market quality characteristics show a strong relationship to the common listing characteristics (with at least three 3, and as many as 4, variables being statistically significant in each model). All four have statistically significant F-statistics (at the $\alpha=.01$ level of significance), and the model explains from $23.23 \%$ to $31.15 \%$ of the variance in the dependent variable.

Model 3 tests for further market quality differences across tiers after controlling for the common listing characteristics. The model specified is:

$$
\begin{aligned}
& M Q=\beta_{0}+\left[\beta_{1} * P R C+\beta_{2} * M M C N T+\beta_{3} * S E+\beta_{4} * S H R O U T+\beta_{5} * \text { MktVal }\right] \\
& +\gamma_{1} * N C M+\gamma_{2} * G S M+\varepsilon
\end{aligned}
$$

Again, the regressions show a relationship between the common listing characteristics and the market quality characteristics, as well as between the dummy variables and the market quality characteristics. All four regressions are statistically significant F-statistics (at the $\alpha=.01$ level of significance), and all improve upon the unexplained variance in the market quality characteristics, by as much as $15.3 \%$.

The results of these regressions are consistent with the hypothesis that listing requirements are related to market quality, but that the unique listing requirements for each tier may also be related to market quality. The model shows that all 4 market quality characteristics still show significant differences across tiers, even after accounting for the common listing standards. As you move from the bottom of the NASDAQ market, effective spreads tighten, price improvement declines, and trading becomes more fragmented across markets. 
Table 3. OLS estimations, effective spread

\begin{tabular}{|c|c|c|c|}
\hline \multicolumn{4}{|c|}{$\begin{array}{l}\text { Dependent variable: Percent Effective Spread is the realized spread, measured } \\
\text { as a percent of the stock price. } \\
\text { Independent variables: PRC is the stock price. MMCNT is the number of } \\
\text { registered market makers. } S E \text { is the Stockholders' Equity. SHROUT is the } \\
\text { number of publicly held shares of stock (i.e. Public Float). Mktval is the market } \\
\text { value of publicly held shares. NCM is a dummy variable equaling } 1 \text { if the stock is } \\
\text { listed on the NASDAQ Capital Market, and } 0 \text { otherwise. GSM is a dummy } \\
\text { variable equaling } 1 \text { if the stock is listed on the Global Select Market, and } 0 \\
\text { otherwise. The NASDAQ Global Market serves as the base case. }\end{array}$} \\
\hline \multirow[t]{2}{*}{ Independent Variables } & \multicolumn{3}{|c|}{ Model } \\
\hline & 1 & 2 & 3 \\
\hline \multirow[t]{2}{*}{$\alpha$} & $4.640 \mathrm{E}-01$ & $1.239 \mathrm{E}+00$ & $9.341 \mathrm{E}-01$ \\
\hline & $<.0001^{* * *}$ & $<.0001^{* * *}$ & $<.0001 * * *$ \\
\hline \multirow[t]{2}{*}{ PRC } & & $-8.540 \mathrm{E}-03$ & $-4.480 \mathrm{E}-03$ \\
\hline & & $<.0001^{* * *}$ & $<.0001 * * *$ \\
\hline \multirow[t]{2}{*}{ MMCNT } & & $-2.108 \mathrm{E}-02$ & $-1.462 \mathrm{E}-02$ \\
\hline & & $<.0001^{* * *}$ & $<.0001 * * *$ \\
\hline \multirow[t]{2}{*}{ SE } & & $8.700 \mathrm{E}-06$ & $1.271 \mathrm{E}-05$ \\
\hline & & 0.4666 & 0.2509 \\
\hline \multirow[t]{2}{*}{ SHROUT } & & $-2.476 \mathrm{E}-07$ & $-1.127 \mathrm{E}-07$ \\
\hline & & $0.0066^{* * *}$ & 0.1836 \\
\hline \multirow[t]{2}{*}{ Mktval } & & $1.889 \mathrm{E}-08$ & 9.587E-09 \\
\hline & & $<.0001 * * *$ & $0.0193 * *$ \\
\hline \multirow[t]{2}{*}{$\mathrm{NCM}$} & 7.104E-01 & & $5.448 \mathrm{E}-01$ \\
\hline & $<.0001 * * *$ & & $<.0001 * * *$ \\
\hline \multirow[t]{2}{*}{ GSM } & $-3.555 \mathrm{E}-01$ & & $-1.437 \mathrm{E}-01$ \\
\hline & $<.0001 * * *$ & & $<.0001 * * *$ \\
\hline $\mathrm{n}$ & 2667 & 2667 & 2667 \\
\hline $\mathrm{F}$ & 609.81 & 219.22 & 249.1 \\
\hline p-value & $<.0001^{* * *}$ & $<.0001 * * *$ & $<.0001 * * *$ \\
\hline Adj-r ${ }^{2}$ & 0.3135 & 0.2917 & 0.3945 \\
\hline
\end{tabular}


Table 4. OLS estimations, price improvement amount

Dependent variable: Price Improvement Amount is the dollar amount of price improvement for trades executed within the quoted spread, measured as a percent of the stock price.

Independent variables: $P R C$ is the stock price. $M M C N T$ is the number of registered market makers. $S E$ is the Stockholders' Equity. SHROUT is the number of publicly held shares of stock (i.e. Public Float). Mktval is the market value of publicly held shares. $N C M$ is a dummy variable equaling 1 if the stock is listed on the NASDAQ Capital Market, and 0 otherwise. $G S M$ is a dummy variable equaling 1 if the stock is listed on the Global Select Market, and 0 otherwise. The NASDAQ Global Market serves as the base case.

\begin{tabular}{|c|c|c|c|}
\hline \multirow[t]{2}{*}{ Independent Variables } & \multicolumn{3}{|c|}{ Model } \\
\hline & 1 & 2 & 3 \\
\hline \multirow[t]{2}{*}{$\alpha$} & $2.500 \mathrm{E}-03$ & $5.640 \mathrm{E}-03$ & 4.370E-03 \\
\hline & $<.0001 * * *$ & $<.0001 * * *$ & $<.0001 * * *$ \\
\hline \multirow[t]{2}{*}{ PRC } & & -0.0000616 & -0.00004547 \\
\hline & & $<.0001 * * *$ & $<.0001 * * *$ \\
\hline \multirow[t]{2}{*}{ MMCNT } & & $-7.259 \mathrm{E}-05$ & $-4.646 \mathrm{E}-05$ \\
\hline & & $<.0001^{* * *}$ & $<.0001 * * *$ \\
\hline \multirow[t]{2}{*}{ SE } & & $1.192 \mathrm{E}-08$ & $2.651 \mathrm{E}-08$ \\
\hline & & 0.8353 & 0.6251 \\
\hline \multirow[t]{2}{*}{ SHROUT } & & $-2.190 \mathrm{E}-09$ & $-1.655 \mathrm{E}-09$ \\
\hline & & $<.0001^{* * *}$ & $<.0001 * * *$ \\
\hline \multirow[t]{2}{*}{ Mktval } & & $1.273 \mathrm{E}-10$ & $9.026 \mathrm{E}-11$ \\
\hline & & $<.0001^{* * *}$ & $<.0001 * * *$ \\
\hline \multirow[t]{2}{*}{$\mathrm{NCM}$} & $2.780 \mathrm{E}-03$ & & $2.280 \mathrm{E}-03$ \\
\hline & $<.0001^{* * *}$ & & $<.0001^{* * *}$ \\
\hline \multirow[t]{2}{*}{ GSM } & $-1.700 \mathrm{E}-03$ & & $-5.301 \mathrm{E}-04$ \\
\hline & $<.0001^{* * *}$ & & $<.0001 * * *$ \\
\hline $\mathrm{n}$ & 2667 & 2667 & 2667 \\
\hline $\mathrm{F}$ & 485.75 & 187.97 & 197.26 \\
\hline $\mathrm{p}$-value & $<.0001 * * *$ & $<.0001 * * *$ & $<.0001^{* * *}$ \\
\hline Adj-r ${ }^{2}$ & 0.2675 & 0.2596 & 0.3401 \\
\hline
\end{tabular}

$* * *, * *, *$ denote statistical significance at the $.01, .05$, and .1 level of significance. $\mathrm{P}$-values reported below regression coefficients. 
Table 5. OLS estimations, price improvement rate

\begin{tabular}{|c|c|c|c|}
\hline $\begin{array}{l}\text { Dependent variable: Price } \\
\text { the quoted spread, measure } \\
\text { Independent variables: } P R \\
\text { market makers. } S E \text { is the } \\
\text { held shares of stock (i.e. Pr } \\
\text { shares. } N C M \text { is a dummy } \\
\text { Capital Market, and } 0 \text { other } \\
\text { listed on the Global Select } \\
\text { serves as the base case. }\end{array}$ & $\begin{array}{l}\text { ement Rate } \\
\text { percent of to } \\
\text { stock price } \\
\text { olders' Equit } \\
\text { oat). Mktva } \\
\text { e equaling } 1 \\
G S M \text { is a do } \\
\text { and } 0 \text { other }\end{array}$ & $\begin{array}{l}\text { percent of } \mathrm{s} \\
\text { ume. } \\
C N T \text { is the } 1 \\
\text { ROUT is the } \\
\text { market val } \\
\text { tock is listec } \\
\text { variable equ } \\
\text { The NASD }\end{array}$ & $\begin{array}{l}\text { xecuted within } \\
\text { of registered } \\
\text { er of publicly } \\
\text { ublicly held } \\
\text { NASDAQ } \\
\text { if the stock is } \\
\text { bal Market }\end{array}$ \\
\hline Independent Variables & & Model & \\
\hline & 1 & 2 & 3 \\
\hline$\alpha$ & $\begin{array}{l}5.440 \mathrm{E}-02 \\
<.0001 * * *\end{array}$ & $\begin{array}{c}6.532 \mathrm{E}-02 \\
<.0001^{* * *}\end{array}$ & $\begin{array}{c}6.194 \mathrm{E}-02 \\
<.0001 * * *\end{array}$ \\
\hline PRC & & $\frac{6.272 \mathrm{E}-04}{<.0001 * * *}$ & $\begin{array}{c}6.474 \mathrm{E}-04 \\
<.0001 * * *\end{array}$ \\
\hline MMCNT & & $\begin{array}{l}-5.908 \mathrm{E}-04 \\
<.0001^{* * *}\end{array}$ & $\begin{array}{l}-5.402 \mathrm{E}-04 \\
<.0001 * * *\end{array}$ \\
\hline SE & & $\frac{-9.103 \mathrm{E}-07}{0.0817^{*}}$ & $\frac{-9.377 \mathrm{E}-07}{0.0722^{*}}$ \\
\hline SHROUT & & $\begin{array}{c}1.825 \mathrm{E}-09 \\
0.6467\end{array}$ & $\begin{array}{c}2.490 \mathrm{E}-09 \\
0.5329\end{array}$ \\
\hline Mktval & & $\begin{array}{c}4.447 \mathrm{E}-11 \\
0.8162\end{array}$ & $\begin{array}{c}-6.757 \mathrm{E}-12 \\
0.9721\end{array}$ \\
\hline $\mathrm{NCM}$ & $\begin{array}{c}9.720 \mathrm{E}-03 \\
<.0001 * * *\end{array}$ & & $\begin{array}{l}7.140 \mathrm{E}-03 \\
<.0001^{* * *}\end{array}$ \\
\hline GSM & $\begin{array}{l}4.270 \mathrm{E}-03 \\
<.0001^{* * *}\end{array}$ & & $\begin{array}{c}7.389 \mathrm{E}-04 \\
0.5318\end{array}$ \\
\hline $\mathrm{n}$ & 2667 & 2667 & 2667 \\
\hline $\mathrm{F}$ & 23.19 & 162.32 & 121.27 \\
\hline $\mathrm{p}$-value & $<.0001 * * *$ & $<.0001 * * *$ & $<.0001 * * *$ \\
\hline Adj-r ${ }^{2}$ & 0.0164 & 0.2323 & 0.2400 \\
\hline
\end{tabular}


Table 6. OLS estimations, Herfindahl-Hirschman Index

$\begin{aligned} & \text { Dependent variable: Herfindahl-Hirschman Index is the measure representing order } \\ & \text { flow fragmentation across major market centers, and ranges from } 0 \text { to } 1 .\end{aligned}$
Independent variables: PRC is the stock price. MMCNT is the number of registered
market makers. SE is the Stockholders' Equity. SHROUT is the number of publicly
held shares of stock (i.e. Public Float). Mktval is the market value of publicly held
shares. NCM is a dummy variable equaling 1 if the stock is listed on the NASDAQ
Capital Market, and 0 otherwise. GSM is a dummy variable equaling 1 if the stock is
listed on the Global Select Market, and 0 otherwise. The NASDAQ Global Market
serves as the base case.

The event study analysis provides a more robust test by looking for immediate, short-term changes in market quality when firms migrate across tiers. Tables 7 through 8 show the daily market quality characteristics for the 41-day window surrounding the listing switch. Table 7 shows equally weighted and value weighted daily averages for firms that rose to a higher tier, while 8 shows equally weighted and value weighted daily averages for firms that dropped to a lower tier. A quick scan of the measures does not reveal any obvious pattern of change in market quality characteristics, and this lack of a change appears robust using equally and value weighted measures, as well as for firms that moved up onto a new tier, or dropped. 
Table 7. Market quality as firms rise to higher tier

\begin{tabular}{|c|c|c|c|c|}
\hline \multicolumn{5}{|c|}{ Equally Weighted } \\
\hline $\begin{array}{c}\text { Trading } \\
\text { Day }\end{array}$ & EffSpread & PI Amt & PI Rate & $\mathrm{HHI}$ \\
\hline-20 & $1.01 \%$ & $0.41 \%$ & $35.01 \%$ & $49.69 \%$ \\
\hline-10 & $0.81 \%$ & $0.27 \%$ & $25.31 \%$ & $46.82 \%$ \\
\hline-9 & $1.00 \%$ & $0.30 \%$ & $32.37 \%$ & $48.42 \%$ \\
\hline-8 & $0.84 \%$ & $0.24 \%$ & $32.77 \%$ & $47.46 \%$ \\
\hline-7 & $0.86 \%$ & $0.27 \%$ & $31.57 \%$ & $44.72 \%$ \\
\hline-6 & $0.80 \%$ & $0.28 \%$ & $30.54 \%$ & $50.71 \%$ \\
\hline-5 & $0.90 \%$ & $0.50 \%$ & $31.83 \%$ & $45.84 \%$ \\
\hline-4 & $1.14 \%$ & $0.30 \%$ & $30.37 \%$ & $46.76 \%$ \\
\hline-3 & $0.95 \%$ & $0.22 \%$ & $34.90 \%$ & $48.18 \%$ \\
\hline-2 & $0.69 \%$ & $0.22 \%$ & $32.49 \%$ & $43.70 \%$ \\
\hline-1 & $0.96 \%$ & $0.26 \%$ & $31.72 \%$ & $46.26 \%$ \\
\hline 0 & $0.81 \%$ & $0.27 \%$ & $33.42 \%$ & $46.08 \%$ \\
\hline 1 & $0.87 \%$ & $0.28 \%$ & $33.63 \%$ & $46.33 \%$ \\
\hline 2 & $1.08 \%$ & $0.27 \%$ & $30.28 \%$ & $46.70 \%$ \\
\hline 3 & $0.90 \%$ & $0.25 \%$ & $32.14 \%$ & $47.25 \%$ \\
\hline 4 & $1.20 \%$ & $0.33 \%$ & $28.52 \%$ & $46.10 \%$ \\
\hline 5 & $1.05 \%$ & $0.35 \%$ & $33.10 \%$ & $45.92 \%$ \\
\hline 6 & $0.99 \%$ & $0.41 \%$ & $34.15 \%$ & $47.26 \%$ \\
\hline 7 & $1.10 \%$ & $0.25 \%$ & $33.24 \%$ & $48.40 \%$ \\
\hline 8 & $0.85 \%$ & $0.24 \%$ & $30.65 \%$ & $46.75 \%$ \\
\hline 9 & $1.04 \%$ & $0.26 \%$ & $30.85 \%$ & $47.68 \%$ \\
\hline 10 & $0.92 \%$ & $0.23 \%$ & $31.35 \%$ & $47.34 \%$ \\
\hline 20 & $1.03 \%$ & $0.23 \%$ & $29.74 \%$ & $45.67 \%$ \\
\hline \multicolumn{5}{|c|}{ Value Weighted } \\
\hline $\begin{array}{c}\text { Trading } \\
\text { Day }\end{array}$ & EffSpread & PI Amt & PI Rate & HHI \\
\hline-20 & $0.36 \%$ & $0.12 \%$ & $20.35 \%$ & $44.93 \%$ \\
\hline-10 & $0.47 \%$ & $0.11 \%$ & $20.58 \%$ & $46.00 \%$ \\
\hline-9 & $0.40 \%$ & $0.14 \%$ & $25.19 \%$ & $42.79 \%$ \\
\hline-8 & $0.36 \%$ & $0.11 \%$ & $23.80 \%$ & $40.03 \%$ \\
\hline-7 & $0.49 \%$ & $0.12 \%$ & $21.47 \%$ & $40.71 \%$ \\
\hline-6 & $0.42 \%$ & $0.12 \%$ & $22.34 \%$ & $42.58 \%$ \\
\hline-5 & $0.40 \%$ & $0.12 \%$ & $20.40 \%$ & $41.45 \%$ \\
\hline-4 & $0.35 \%$ & $0.10 \%$ & $20.13 \%$ & $40.96 \%$ \\
\hline-3 & $0.61 \%$ & $0.11 \%$ & $19.96 \%$ & $41.70 \%$ \\
\hline-2 & $0.37 \%$ & $0.12 \%$ & $23.83 \%$ & $40.31 \%$ \\
\hline-1 & $0.38 \%$ & $0.12 \%$ & $20.32 \%$ & $41.78 \%$ \\
\hline 0 & $0.42 \%$ & $0.13 \%$ & $22.02 \%$ & $44.01 \%$ \\
\hline 1 & $0.46 \%$ & $0.12 \%$ & $22.83 \%$ & $40.74 \%$ \\
\hline 2 & $0.45 \%$ & $0.13 \%$ & $21.42 \%$ & $42.87 \%$ \\
\hline 3 & $0.37 \%$ & $0.11 \%$ & $20.84 \%$ & $44.03 \%$ \\
\hline 4 & $0.46 \%$ & $0.14 \%$ & $23.14 \%$ & $41.30 \%$ \\
\hline 5 & $0.41 \%$ & $0.14 \%$ & $23.94 \%$ & $41.35 \%$ \\
\hline 6 & $0.48 \%$ & $0.13 \%$ & $20.40 \%$ & $40.21 \%$ \\
\hline 7 & $0.48 \%$ & $0.13 \%$ & $21.80 \%$ & $52.66 \%$ \\
\hline 8 & $0.35 \%$ & $0.12 \%$ & $23.15 \%$ & $40.61 \%$ \\
\hline 9 & $0.41 \%$ & $0.14 \%$ & $24.13 \%$ & $42.11 \%$ \\
\hline 10 & $0.44 \%$ & $0.11 \%$ & $24.85 \%$ & $42.18 \%$ \\
\hline 20 & $0.53 \%$ & $0.16 \%$ & $18.68 \%$ & $38.74 \%$ \\
\hline
\end{tabular}


Table 8. Market quality as firms drop to lower tier

\begin{tabular}{|c|c|c|c|c|}
\hline \multicolumn{5}{|c|}{ Equally Weighted } \\
\hline $\begin{array}{c}\text { Trading } \\
\text { Day }\end{array}$ & EffSpread & PI Amt & PI Rate & $\mathrm{HHI}$ \\
\hline-20 & $3.55 \%$ & $1.16 \%$ & $33.04 \%$ & $48.97 \%$ \\
\hline-10 & $3.99 \%$ & $1.03 \%$ & $34.00 \%$ & $51.06 \%$ \\
\hline-9 & $4.33 \%$ & $1.28 \%$ & $32.15 \%$ & $52.88 \%$ \\
\hline-8 & $4.08 \%$ & $2.74 \%$ & $30.40 \%$ & $52.60 \%$ \\
\hline-7 & $4.27 \%$ & $1.34 \%$ & $26.02 \%$ & $53.18 \%$ \\
\hline-6 & $4.15 \%$ & $1.37 \%$ & $31.62 \%$ & $51.12 \%$ \\
\hline-5 & $4.00 \%$ & $1.12 \%$ & $27.75 \%$ & $50.06 \%$ \\
\hline-4 & $5.02 \%$ & $1.43 \%$ & $31.57 \%$ & $52.14 \%$ \\
\hline-3 & $4.69 \%$ & $1.38 \%$ & $35.23 \%$ & $53.56 \%$ \\
\hline-2 & $4.14 \%$ & $1.14 \%$ & $29.95 \%$ & $50.35 \%$ \\
\hline-1 & $4.17 \%$ & $1.31 \%$ & $25.97 \%$ & $50.72 \%$ \\
\hline 0 & $5.02 \%$ & $1.34 \%$ & $32.40 \%$ & $52.71 \%$ \\
\hline 1 & $4.51 \%$ & $1.62 \%$ & $34.04 \%$ & $51.16 \%$ \\
\hline 2 & $4.01 \%$ & $1.01 \%$ & $30.99 \%$ & $53.60 \%$ \\
\hline 3 & $4.33 \%$ & $1.26 \%$ & $28.55 \%$ & $50.22 \%$ \\
\hline 4 & $4.57 \%$ & $1.18 \%$ & $38.66 \%$ & $53.80 \%$ \\
\hline 5 & $4.56 \%$ & $1.84 \%$ & $32.90 \%$ & $53.08 \%$ \\
\hline 6 & $3.89 \%$ & $1.34 \%$ & $32.58 \%$ & $49.20 \%$ \\
\hline 7 & $5.73 \%$ & $1.41 \%$ & $31.51 \%$ & $49.13 \%$ \\
\hline 8 & $4.28 \%$ & $2.12 \%$ & $36.30 \%$ & $52.12 \%$ \\
\hline 9 & $4.51 \%$ & $1.20 \%$ & $33.77 \%$ & $51.80 \%$ \\
\hline 10 & $4.70 \%$ & $1.62 \%$ & $32.73 \%$ & $52.65 \%$ \\
\hline 20 & $4.81 \%$ & $1.47 \%$ & $36.95 \%$ & $54.39 \%$ \\
\hline \multicolumn{5}{|c|}{ Value Weighted } \\
\hline $\begin{array}{c}\text { Trading } \\
\text { Day }\end{array}$ & EffSpread & PI Amt & PI Rate & $\mathrm{HHI}$ \\
\hline-20 & $1.99 \%$ & $0.50 \%$ & $22.44 \%$ & $42.27 \%$ \\
\hline-10 & $2.55 \%$ & $0.68 \%$ & $26.23 \%$ & $46.12 \%$ \\
\hline-9 & $2.32 \%$ & $0.53 \%$ & $25.04 \%$ & $47.14 \%$ \\
\hline-8 & $2.26 \%$ & $0.72 \%$ & $25.53 \%$ & $45.69 \%$ \\
\hline-7 & $2.17 \%$ & $0.63 \%$ & $19.76 \%$ & $43.29 \%$ \\
\hline-6 & $2.09 \%$ & $0.62 \%$ & $19.23 \%$ & $43.34 \%$ \\
\hline-5 & $2.09 \%$ & $0.56 \%$ & $16.56 \%$ & $44.46 \%$ \\
\hline-4 & $2.38 \%$ & $0.67 \%$ & $26.42 \%$ & $52.04 \%$ \\
\hline-3 & $2.59 \%$ & $0.78 \%$ & $24.24 \%$ & $49.68 \%$ \\
\hline-2 & $2.17 \%$ & $0.91 \%$ & $13.98 \%$ & $55.61 \%$ \\
\hline-1 & $3.80 \%$ & $1.11 \%$ & $22.01 \%$ & $45.45 \%$ \\
\hline 0 & $3.50 \%$ & $1.06 \%$ & $25.82 \%$ & $45.50 \%$ \\
\hline 1 & $2.82 \%$ & $0.85 \%$ & $24.74 \%$ & $45.67 \%$ \\
\hline 2 & $3.20 \%$ & $0.87 \%$ & $23.54 \%$ & $48.84 \%$ \\
\hline 3 & $3.33 \%$ & $0.77 \%$ & $22.43 \%$ & $46.29 \%$ \\
\hline 4 & $2.20 \%$ & $0.66 \%$ & $31.94 \%$ & $52.36 \%$ \\
\hline 5 & $3.08 \%$ & $0.80 \%$ & $23.36 \%$ & $46.56 \%$ \\
\hline 6 & $2.35 \%$ & $0.70 \%$ & $24.07 \%$ & $45.33 \%$ \\
\hline 7 & $2.27 \%$ & $0.57 \%$ & $18.39 \%$ & $43.71 \%$ \\
\hline 8 & $2.82 \%$ & $0.79 \%$ & $20.42 \%$ & $44.35 \%$ \\
\hline 9 & $2.54 \%$ & $0.77 \%$ & $23.45 \%$ & $45.89 \%$ \\
\hline 10 & $2.43 \%$ & $0.67 \%$ & $22.78 \%$ & $43.97 \%$ \\
\hline 20 & $2.46 \%$ & $0.39 \%$ & $27.25 \%$ & $42.30 \%$ \\
\hline
\end{tabular}

Figures 1 through 4 graphically display the value-weighted measure results on the daily market quality measures (equally weighted are not reported, but are consistent with the value-weighted charts). Note that short-term, 
immediate shifts do not appear to occur for any of the four market quality measures. In fact, only Figure 1 illustrates any sort of trend, with effective spreads appearing to increase in the 20 days after firms dropped to a lower tier.

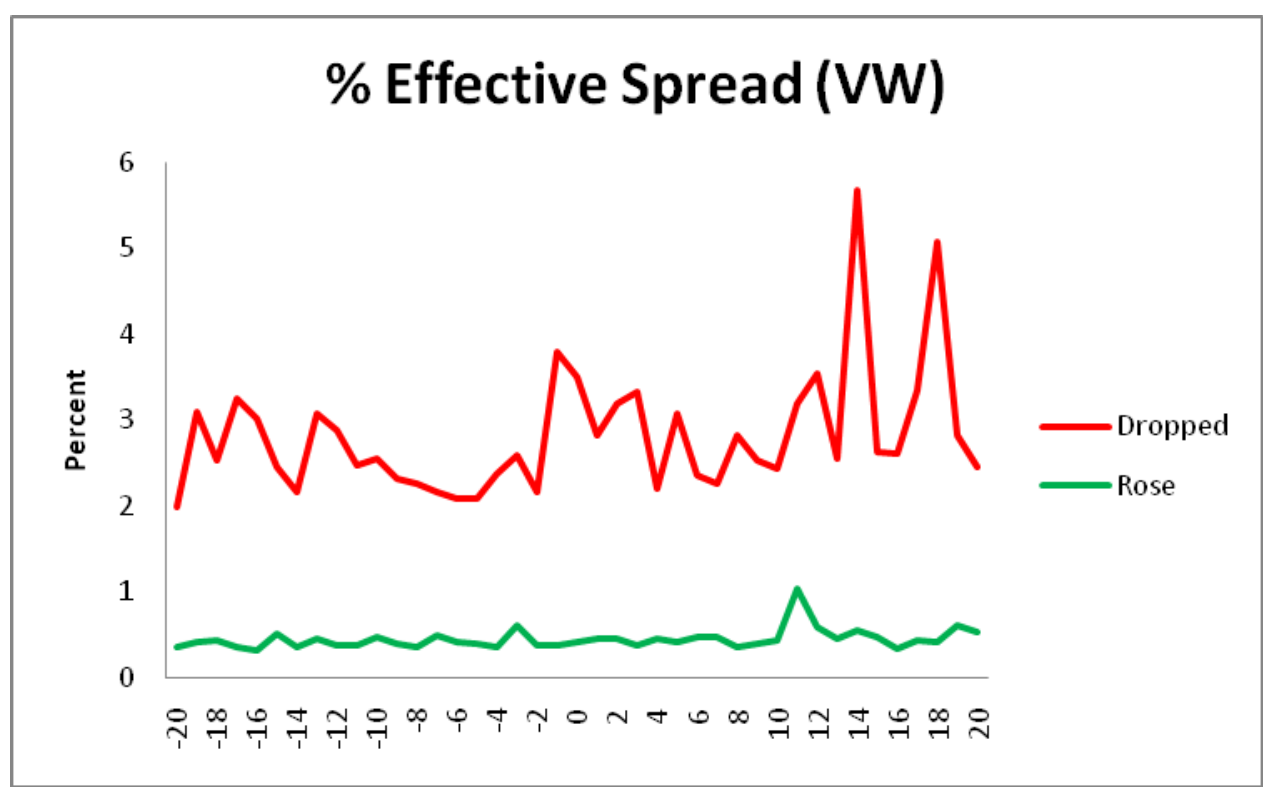

Figure 1. Percent effective spread (Value weighted)

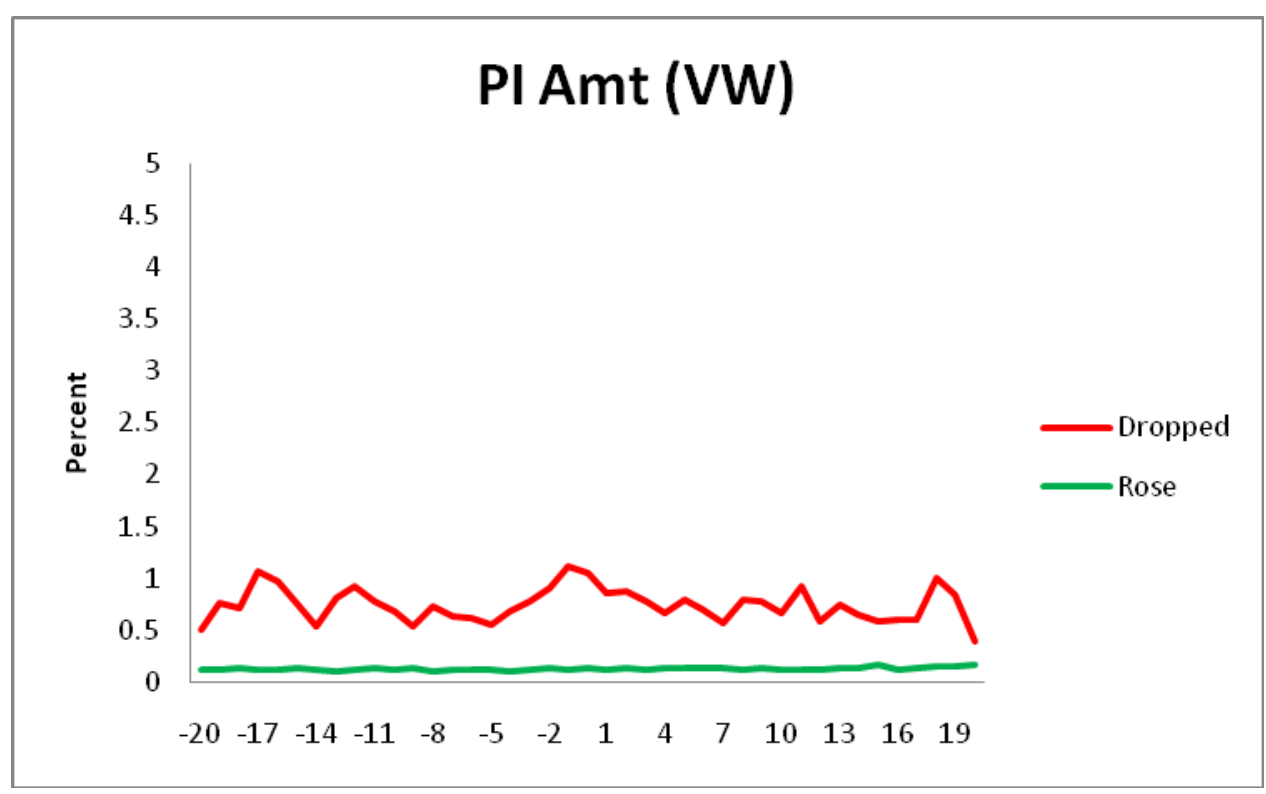

Figure 2. Percent price improvement amount (Value weighted). 


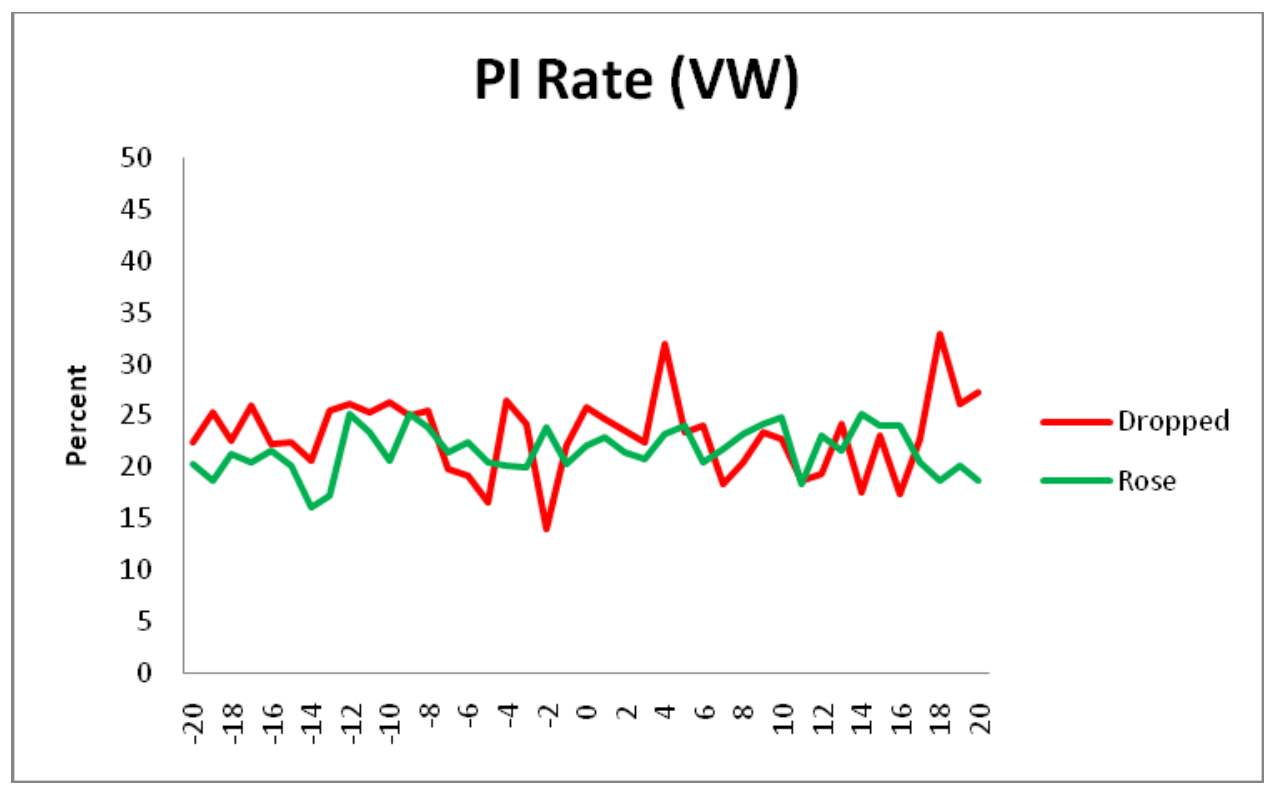

Figure 3. Price improvement rate (Value weighted)

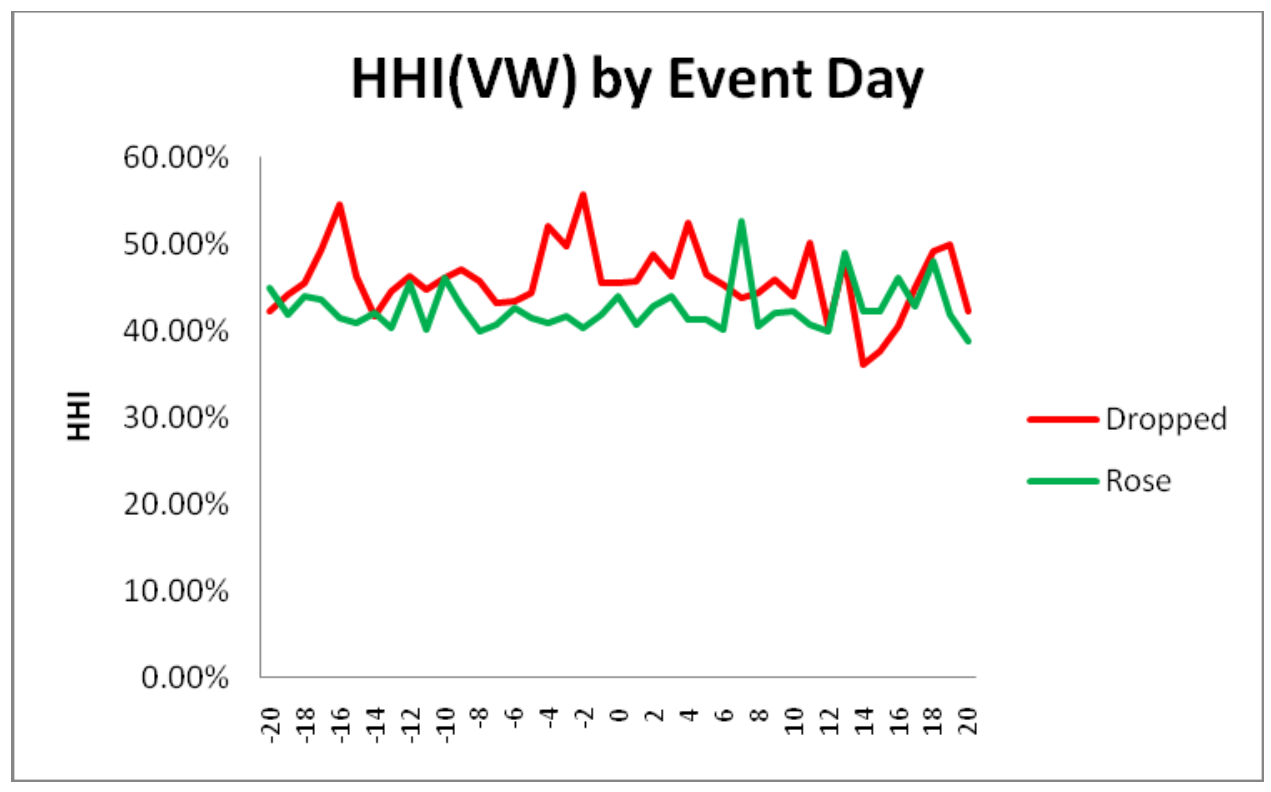

Figure 4. Herfindahl-Hirshman Index (Value weighted)

Table 9 shows the results of T-tests comparing market quality measures post-switch versus pre-switch. Percent Effective Spreads appear to increase when stocks both rise and drop onto new tiers. This finding is robust for equal and value weighted for stocks that drop, but not for firms that rise. All other market quality measures fail to show any significant, robust pattern of short-term changes in market quality in the immediate days surrounding a listing switch. Event study analysis appears to rule out short-term changes in market quality, with the possible exception of effective spreads. 
Table 9. T-tests for market quality differences

\begin{tabular}{|c|c|c|c|c|c|}
\hline \multicolumn{6}{|c|}{ Pre-Post Market Quality Differences } \\
\hline & & \multicolumn{2}{|c|}{$\begin{array}{l}\text { Dropping to } \\
\text { Lower Tier }\end{array}$} & \multicolumn{2}{|c|}{$\begin{array}{l}\text { Rising to } \\
\text { Higher Tier }\end{array}$} \\
\hline & & EW & VW & EW & VW \\
\hline \multirow{4}{*}{ EffSpread } & Post & $4.57 \%$ & $3.05 \%$ & $0.96 \%$ & $0.49 \%$ \\
\hline & Pre & $4.22 \%$ & $2.57 \%$ & $0.96 \%$ & $0.41 \%$ \\
\hline & Diff (Post-Pre) & $0.35 \%$ & $0.48 \%$ & $0.00 \%$ & $0.08 \%$ \\
\hline & p-value & $0.0187 * *$ & $0.0625^{*}$ & 0.9819 & $0.0377 * *$ \\
\hline \multirow{4}{*}{ PI Rate } & Post & $32.86 \%$ & $23.21 \%$ & $31.44 \%$ & $22.02 \%$ \\
\hline & Pre & $32.06 \%$ & $22.87 \%$ & $31.63 \%$ & $21.11 \%$ \\
\hline & Diff (Post-Pre) & $0.80 \%$ & $0.34 \%$ & $-0.20 \%$ & $0.91 \%$ \\
\hline & p-value & 0.3723 & 0.7609 & 0.7926 & 0.1518 \\
\hline \multirow{4}{*}{ PI Amt } & Post & $1.42 \%$ & $0.72 \%$ & $0.28 \%$ & $0.13 \%$ \\
\hline & Pre & $1.35 \%$ & $0.75 \%$ & $0.29 \%$ & $0.12 \%$ \\
\hline & Diff (Post-Pre) & $0.08 \%$ & $-0.03 \%$ & $-0.01 \%$ & $0.01 \%$ \\
\hline & p-value & 0.4306 & 0.5513 & 0.5746 & $0.0027 * *$ \\
\hline \multirow{4}{*}{ HHI } & Post & $51.80 \%$ & $45.12 \%$ & $46.72 \%$ & $42.99 \%$ \\
\hline & Pre & $51.93 \%$ & $46.62 \%$ & $46.84 \%$ & $42.15 \%$ \\
\hline & Diff (Post-Pre) & $-0.13 \%$ & $-1.50 \%$ & $-0.13 \%$ & $0.84 \%$ \\
\hline & p-value & 0.8143 & 0.1212 & 0.7622 & 0.3787 \\
\hline & & \multicolumn{2}{|c|}{$\mathrm{n}=74$} & \multicolumn{2}{|c|}{$\mathrm{n}=84$} \\
\hline
\end{tabular}

Regardless, the lack of a clear short-term change consistent with the cross-section findings does not necessarily rule out the possibility of a long-term change, or a change preceding the event window. The possibilities exist that the disclosure process occurs slowly, as companies release future financial statements and make information publicly available through press releases. Additionally, a company may exceed the listing requirements for their current tier, and the listing change occurs after-the-fact, when the disclosure process may have already revealed new information to the marketplace. These possibilities will require further analysis in subsequent studies.

\section{Conclusion}

This study analyzes the relationship between listing standards and market quality. Previous studies focused on the effects of different disclosure requirements on market quality. These studies suffered from joint hypothesis problems due to analyzing market quality for stocks listed on different exchanges, thereby leaving entangled any effects of different listing requirements (which had not been tested) and different market structures (which is well-documented in the literature). Using NASDAQ's unique tiered structure, we control for disclosure requirements and market structure to resolve the joint hypothesis problem. My cross-sectional analysis indicates a statistical relationship between listing standards and market quality. However, a short-term analysis of changes in market quality fails to detect any material changes in the 20 trading days immediately after a firm switches tiers.

The combination of the cross-sectional and temporal analyses is consistent with an explanation that market quality differences evolve more slowly through the disclosure process, rather than instantly when a company moves onto a tier with different listing requirements. An alternate scenario also consistent with the evidence is that the disclosure process is highly efficient, where market quality already reflects information contained in the new listing standards.

This study indicates that listing requirements comprise a component of the information set made available to investors, and the disclosure process helps reveal that information set. Future research should focus on the speed at which the disclosure process reveals this information, without co-mingling different market structures and disclosure standards.

A potential way to test the efficiency of the disclosure process stocks would be to track when NASDAQ discloses firms failing to meet listing standards for a specific tier, and then testing whether or not those disclosures quickly result in changes in market quality. In these cases, the listings standards and market structure are being held constant, 
and the disclosure impact could be isolated. This approach also avoids the joint hypothesis problems from earlier studies on the disclosure-liquidity relationship, since these stocks would all face the same listing requirements, the same regulatory environment, and the same market microstructure.

\section{References}

Alexander, G., \& Peterson, M. (2008). The effect of price tests on trader behavior and market quality: An analysis of Reg SHO. Journal of Financial Markets, 11, 84-111. http://dx.doi.org/10.1016/j.finmar.2007.06.002

Bennett, P., \& Wei, L. (2006). Market structure, fragmentation, and market quality. Journal of Financial Markets, 9 , 49-78. http://dx.doi.org/10.1016/j.finmar.2005.12.001

Chavez, G., \& Silva, A. (2006). Improved Corporate Governance: Market Reaction and Liquidity Implications. Working Studys Economia wp06-08, Instituto de Empresa, Area of Economic Environment. http://dx.doi.org/10.2139/ssrn.1014656

Chemmanur, T., \& Fulghieri, P. (2006, Nov.). Competition and cooperation among exchanges: A theory of cross-listing and endogenous listing standards. Journal of Financial Economics, 82(2), 455-489. http://dx.doi.org/10.1016/j.jfineco.2005.06.008

Draus, S. (2009). Liquidity Effects of Listing Requirements. 2009 Annual Meeting, European Financial Management Association. http://dx.doi.org/10.2139/ssrn.1364091

Easley, D., Kiefer, N., \& O'Hara, M. (2007). Microstructure and Ambiguity. Western Finance Association Meeting.

Eom, K., Ok, J., \& Park, J. (2007). Pre-trade transparency and market quality. Journal of Financial Markets, 10, 319-341. http://dx.doi.org/10.1016/j.finmar.2007.06.001

Foucault, T., \& Parlour, C. (2004). Competition for Listings. RAND Journal of Economics, 35(2), 329-355. http://dx.doi.org/10.2307/1593694

Frost, C., \& Botosan, C. (1997). Regulation, Disclosure and Market Liquidity (An Examination of Foreign Issuers in Regulated Versus Less-Regulated US Equity Markets). Retrieved from http://ssrn.com/abstract=10618

Frost, C., Gordon, E., \& Hayes, A. (2006). Stock Exchange Disclosure and Market Development: An Analysis of 50 International Exchanges. Journal of Accounting Research, 44(3), 437-483. http://dx.doi.org/10.1111/j.1475-679X.2006.00208.x

Healy, P., Hutton, A., \& Palepu, K. (1999). Stock Performance and Intermediation Changes Surrounding Sustained Increases in Disclosure. Contemporary Accounting Research, 16, 485-520. http://dx.doi.org/10.1111/j.1911-3846.1999.tb00592.x

Heflin, F., Shaw, K., \& Wildo, J. (2005). Disclosure Policy and Market Liquidity: Impact of Depth Quotes and Order Sizes. Contemporary Accounting Research, 22, 829-865. http://dx.doi.org/10.1506/EETM-FALM-4KDD-9DT9

Hendershott, T., \& Jones, C. (2005). Trade-through prohibitions and market quality. Journal of Financial Markets, 8 , 1-23. http://dx.doi.org/10.1016/j.finmar.2004.09.001

Leuz, C., \& Verrechia, R. (2000). The Economic Consequences of Increased Disclosure. Journal of Accounting Research, 38, 91-124. http://dx.doi.org/10.2307/2672910

NASDAQ Press Release, NASDAQ Creates New Market Tier with Highest Listing Standards In the World, Feb. $15^{\text {th }}$, 2006.

Shkilko, A., Van Ness, B., \& Van Ness, R. (2008). Locked and Crossed Markets on NASDAQ and the NYSE. Journal of Financial Markets, 11(3), 199-338. http://dx.doi.org/10.1016/j.finmar.2007.02.001

Theobald, M., \& Yallup, P. (2004). Determining security speed of adjustment coefficients. Journal of Financial Markets, 7, 75-96. http://dx.doi.org/10.1016/S1386-4181(02)00068-X

Welker, M. (1995). Disclosure Policy, Information Asymmetry, and Liquidity in Equity Markets. Contemporary Accounting Research, 11, 801-827. http://dx.doi.org/10.1111/j.1911-3846.1995.tb00467.x

Zhao, X., \& Chung, K. (2007). Information Disclosure and Market Quality: The Effect of SEC Rule 605 on Trading Costs. Journal of Financial and Quantitative Analysis, 42(3), 657-682. http://dx.doi.org/10.1017/S0022109000004130 
Appendix A

\begin{tabular}{|c|c|c|c|c|c|c|c|c|}
\hline & \multirow{2}{*}{ Requirements } & \multicolumn{3}{|c|}{ Global Select } & \multicolumn{3}{|c|}{ Global } & \multirow[t]{2}{*}{ Capital } \\
\hline & & 1 & 2 & 3 & 1 & 2 & 3 & \\
\hline \multirow{9}{*}{ 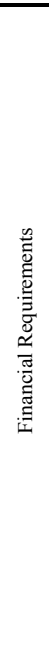 } & Pre-tax earnings & $\begin{array}{c}\text { Aggregate in prior three } \\
\text { fiscal years }>\$ 11 \mathrm{M} \\
\& \\
\text { Two most recent fiscal } \\
\text { years }>\$ 2.2 \mathrm{M} \\
\& \\
\text { Each of the prior } 3 \text { fiscal } \\
\text { years }>\$ 0\end{array}$ & $\mathrm{n} / \mathrm{a}$ & $\mathrm{n} / \mathrm{a}$ & $\$ 1 M$ & $\mathrm{n} / \mathrm{a}$ & $\mathrm{n} / \mathrm{a}$ & $\begin{array}{c}\$ .75 \mathrm{M}^{1} \\
\text { (Net income) }\end{array}$ \\
\hline & Cash flows & $\mathrm{n} / \mathrm{a}$ & $\begin{array}{c}\text { Aggregate in prior } 3 \\
\text { fiscal years }>\$ 27.5 \mathrm{M} \\
\& \\
\text { Each of the prior } 3 \\
\text { fiscal years }>\$ 0\end{array}$ & $\mathrm{n} / \mathrm{a}$ & $\mathrm{n} / \mathrm{a}$ & $\mathrm{n} / \mathrm{a}$ & $\mathrm{n} / \mathrm{a}$ & $\mathrm{n} / \mathrm{a}$ \\
\hline & Market capitalization & $\mathrm{n} / \mathrm{a}$ & $\begin{array}{c}\text { Average }>\$ 550 \mathrm{M} \\
\text { over prior } 12 \text { months }\end{array}$ & $\begin{array}{c}\text { Average }>\$ 850 \mathrm{M} \text { over } \\
\text { prior } 12 \text { months }\end{array}$ & $\mathrm{n} / \mathrm{a}$ & $\mathrm{n} / \mathrm{a}$ & $\mathrm{n} / \mathrm{a}$ & $\$ 50 \mathrm{M}^{1}$ \\
\hline & Revenue & $\mathrm{n} / \mathrm{a}$ & $\begin{array}{l}\text { Previous fiscal year } \\
>\$ 110 \mathrm{M}\end{array}$ & $\begin{array}{c}\text { Previous fiscal year }> \\
\$ 90 \mathrm{M}\end{array}$ & $\mathrm{n} / \mathrm{a}$ & $\mathrm{n} / \mathrm{a}$ & $\mathrm{n} / \mathrm{a}$ & $\mathrm{n} / \mathrm{a}$ \\
\hline & Minimum bid price & \multicolumn{3}{|c|}{$\$ 5.00$} & \multicolumn{3}{|c|}{$\$ 5.00$} & $\$ 4.00$ \\
\hline & Minimum market makers & \multicolumn{3}{|c|}{3} & 3 & 3 & 4 & 3 \\
\hline & Stockholders' Equity & \multicolumn{3}{|c|}{$\mathrm{n} / \mathrm{a}$} & $\$ 15 \mathrm{M}$ & $\$ 30 \mathrm{M}$ & $\mathrm{n} / \mathrm{a}$ & $\$ 5 \mathrm{M}^{1}$ \\
\hline & Operating history & \multicolumn{3}{|c|}{$\mathrm{n} / \mathrm{a}$} & $\mathrm{n} / \mathrm{a}$ & 2 years & $\mathrm{n} / \mathrm{a}$ & $\mathrm{n} / \mathrm{a}$ \\
\hline & Corporate governance & \multicolumn{3}{|c|}{ Yes } & \multicolumn{3}{|c|}{ Yes } & Yes \\
\hline \multirow{4}{*}{ 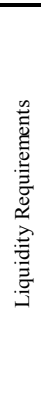 } & $\begin{array}{c}\text { Beneficial shareholders } \\
\text { or } \\
\text { Beneficial shareholders } \\
\text { and Avg mo vol over past } 12 \mathrm{mos}\end{array}$ & \multicolumn{3}{|c|}{2,200} & \multicolumn{3}{|c|}{$\begin{array}{c}400 \\
\text { (round lot } \\
\text { holders) }\end{array}$} & $\begin{array}{c}300 \\
\text { (round lot } \\
\text { holders) }\end{array}$ \\
\hline & Publicly held shares & \multicolumn{3}{|c|}{$1.25 \mathrm{M}$} & \multicolumn{3}{|c|}{$1.1 \mathrm{M}$} & $1 \mathrm{M}$ \\
\hline & $\begin{array}{l}\text { Market value of public shares } \\
\text { or } \\
\text { Market value of public shares and } \\
\text { Shareholders' equity }\end{array}$ & \multicolumn{3}{|c|}{$\begin{array}{c}\$ 110 \text { million } \\
\text { or } \\
\$ 100 \text { million and } \$ 110 \text { million }\end{array}$} & $\$ 8 \mathrm{M}$ & $\$ 18 \mathrm{M}$ & $\$ 20 \mathrm{M}$ & $\mathrm{n} / \mathrm{a}$ \\
\hline & $\begin{array}{l}\text { Market value of listed securities } \\
\text { or } \\
\text { Total assets and Total revenue }\end{array}$ & \multicolumn{3}{|c|}{$\mathrm{n} / \mathrm{a}$} & $\mathrm{n} / \mathrm{a}$ & $\mathrm{n} / \mathrm{a}$ & $\begin{array}{c}\$ 75 \mathrm{M} \\
\text { or } \\
\$ 75 \mathrm{M} \text { and } \\
\$ 75 \mathrm{M}\end{array}$ & $\mathrm{n} / \mathrm{a}$ \\
\hline
\end{tabular}

Initial Listing Standards.

Appendix B

\begin{tabular}{|c|c|c|c|c|c|c|c|}
\hline & \multicolumn{2}{|c|}{ GSM } & \multicolumn{2}{|c|}{ GM } & \multicolumn{3}{|c|}{$\mathrm{CM}$} \\
\hline & Standard 1 & Standard 2 & Standard 1 & Standard 2 & Standard 1 & Standard 2 & Standard 3 \\
\hline Stockholders' equity & $\$ 10,000,000$ & $\mathrm{~N} / \mathrm{A}$ & $\$ 10,000,000$ & N/A & $\$ 2,500,000$ & $\mathrm{~N} / \mathrm{A}$ & N/A \\
\hline Market value of listed securities & N/A & $\$ 50,000,000$ & N/A & $\$ 50,000,000$ & N/A & $\$ 35,000,000$ & N/A \\
\hline or & & or & & or & & & \\
\hline Total assets and total revenue & & $\$ 50 \mathrm{~m}$ and $\$ 50 \mathrm{~m}$ & & $\$ 50 \mathrm{~m}$ and $\$ 50 \mathrm{~m}$ & N/A & N/A & $\$ 500,000$ \\
\hline Publicly held shares & 750,000 & $1,100,000$ & 750,000 & $1,100,000$ & 500,000 & 500,000 & 500,000 \\
\hline Market value of publicly held shares & $\$ 5,000,000$ & $\$ 15,000,000$ & $\$ 5,000,000$ & $\$ 15,000,000$ & $\$ 1,000,000$ & $\$ 1,000,000$ & $\$ 1,000,000$ \\
\hline Bid price & $\$ 1$ & $\$ 1$ & $\$ 1$ & $\$ 1$ & $\$ 1$ & $\$ 1$ & $\$ 1$ \\
\hline Shareholders (round lot holders) & 400 & 400 & 400 & 400 & 300 & 300 & 300 \\
\hline Market makers & 2 & 4 & 2 & 4 & 2 & 2 & 2 \\
\hline Corporate governance & Yes & Yes & Yes & Yes & Yes & Yes & Yes \\
\hline
\end{tabular}

Continued Listing Standards. 